the extinction fell immediately to the initial value. This action of acetaldehyde in presence of alcohol apo-dehydrogenase indicates that the reduced coenzyme was identical with dihydro-co-zymase.

(3) In a mixture of $0.2 \mathrm{mgm}$. co-zymase, $0.3 \mathrm{ml}$. $M / 2$ phosphate buffer $p \mathrm{H}=7 \cdot 6,0 \cdot 1 \mathrm{ml}$. alcohol apodehydrogenase, $0.2 \mathrm{ml}$. absolute alcohol and $3.5 \mathrm{ml}$. water, dihydro-co-zymase was produced and recognized by its characteristic absorption at $334 \mathrm{~m} \mu$ (Fig. 3). After attainment of equilibrium, the apo-

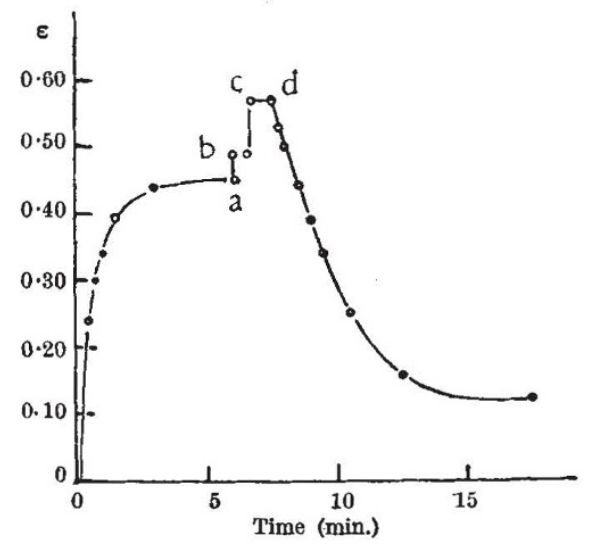

FIG. 3.

dehydrogenase was destroyed by heating $(a)$; the extinction rose to $(b)$ owing to a slight turbidity. Addition of $0.1 \mathrm{ml}$. $M / 10$ pyruvate caused an immediate increase to $(c)$, due to the pyruvate itself, but on further addition of $0.1 \mathrm{ml}$. lactic apo-dehydrogenase $(d)$, the extinction fell by an amount representing the reoxidation of the dihydro-cozymase. It follows that dihydro-co-zymase can act as the prosthetic group of lactic dehydrogenase in the reduction of pyruvic acid to lactic acid.

These three experiments show that the co-enzyme of lactic dehydrogenase is identical with that of alcohol dehydrogenase and therefore with co-zymase. The reduction of pyruvic acid to lactic acid in muscle glycolysis probably involves dihydro-co-zymase. Further details will be given elsewhere.

E. Apler.

H. v. EULER.

Biochemical Institute,

H. Hellström.

Stockholm

Oct. 23.

1 Euler, Adler and Hellström, Z. physiol. Chem., 241, 239 (1936).

2 Euler and Adler, Z. physiol. Chem. 238, 233 (1936).

3 Adler and Michaelis, Z. physiol. Chem., 238, 261 (1936).

- Green and Brosteaux, Biochem. J., 30, 1489 (1936).

\section{The Sterckfontein Ape}

In NatuRe of September 19, Dr. R. Broom, of Pretoria, has given an account of the important discovery of a Pleistocene anthropoid skull at Sterckfontein, near Johannesburg, Transvaal, and has supplemented it simultaneously by a series of excellent photographs both of the site and specimen which have appeared in the Illustrated London News. In Nature of October 24, p. 719, he has given a figure and description of the teeth. He maintains that the Sterckfontein specimen belongs to the same genus Australopithecus, although to another species, as the Taungs ape, and that both are hominoid, and not nearly related to any of the existing species of anthropoids.

In examining the cast of the Taungs specimen in the British Museum, and the photographs of the teeth published by various authors, notably by $W$. $\mathrm{Abel}^{1}$, the conclusion could not be avoided that these teeth are not human at all but are more like those of the gorilla. As regards the skull of the baby specimen from Taungs, it shows features which are decidedly gorilloid. The concave profile of the face (taken to be chimpanzoid by Dart) can easily be explained by deformation, proof of which is the crack at the root of the nasals. The nasals themselves are fairly big, but appear smaller than they really are, because the lower end is broken off, and the nasal aperture therefore distorted. Other features which the skull has in common with the gorilla are the length of the brain case, and the fact that the suture between the maxillary and the zygomatic runs medially to the masseteric knob, whereas in the chimpanzee, for example, it runs laterally. The size of the Taungs ape is smaller than that of any recent gorilla of corresponding age. The Sterckfontein skull is that of an adult animal. Its size again is smaller than that of the existing gorilla. But this reduction in size is on about the same level as in the Taungs ape. The teeth figured by Dr. Broom are quite unlike those of man or of the chimpanzee. In both of these they are roundish in outline, and the heel of the last molar is shortened and the individual cusps more or less fused into a ridge. In the Sterckfontein skull, and in the gorilla, the cheek teeth are more rectangular in cross-section, and the last molar has a well-developed heel with two distinct cusps (and a postero-external style). The structure of this tooth in Dr. Broom's specimen can be matched by that found in a female gorilla from the Okuni district, South Nigeria (Brit. Mus. No. 7.1.8.4).

Dr. Broom has maintained that one of the most important features proving the affinity of Australopithecus and man was the fact that the lateral incisors of the upper jaw and the canines meet, a feature which he thinks does not occur in apes. This may be true in normal chimpanzees and gorillas. But it is not quite true in the pigmy chimpanzee (Pan satyrus paniscus) found south of the Congo, where the space between these two teeth has become very small indeed. This animal, as has been pointed out before, presents a case homologous to Australopithecus ${ }^{2}$. The small size, the dome-shaped forehead, the shortness of the face which is responsible for the crowding together of the teeth, are the same in both. It is, therefore, very probable that Australopithecus was a pigmy gorilla. From the relative size of the two specimens known and the smallness of the canine teeth, it appears that both were females.

The fact that Dr. Broom's specimen does not represent an ancestral form of the hominoid line does not detract from the extreme value of the discovery. It is to be hoped that he will be able to continue his researches, and to elucidate the history of anthropoids in Africa, an undertaking quite as important and interesting as that of the ancestors of man himself.

ERNST SCHWARz.

18 Taviton Street,

London, W.C.1.

Oct. 27.

${ }^{1}$ Morphol. Jahrb., 65, 539-640 (1931).

${ }^{2}$ Ann. Mag. Nat. Hist. (10), 13, 583 (1934). 